Annals of Warsaw University of Life Sciences - SGGW

Land Reclamation No 47 (2), 2015: 113-126

(Ann. Warsaw Univ. Life Sci. - SGGW, Land Reclam. 47 (2), 2015)

\title{
A simplified algorithm for the design of piled raft foundations applied for the case study of a building erected within Żoliborz-Szczęśliwice glacial tunnel valley
}

\author{
GRZEGORZ KACPRZAK ${ }^{1}$, KATARZYNA MAZUREK ${ }^{1}$, TOMASZ DAKTERA ${ }^{2}$ \\ ${ }^{1}$ Institute of Roads and Bridges, Warsaw University of Technology \\ ${ }^{2}$ Ecole des Ponts et Chaussees ParisTech
}

\begin{abstract}
A simplified algorithm for the design of piled raft foundations applied for the case study of a building erected within Żoliborz-Szczęśliwice glacial tunnel valley. A common engineering solution for excessive settlement with raft foundation $(s)$ is the use of piles in order to reduce the vertical displacements, in this method, the whole structural load is transferred to the piles. This is an overly cautious approach, and there remains a need to find an optimal design method for a building's foundations. Such a solution may be the piled raft foundation, which allows a reduction of the number of piles due to the integration of the raft in the bearing capacity of the foundation. The aim of the article is to estimate the contribution of foundation elements such as the raft and the piles in the bearing capacity of a residential building located in Warsaw, where the geological conditions are characterized by organic soil layers, principally of gyttja.
\end{abstract}

Key words: piled raft foundation, glacial tunnel valley

\section{INTRODUCTION}

A common engineering solution for excessive settlement with traditional foundations is the use of piles in order to reduce the vertical displacements. In this method, the whole structural load is transferred to the piles. This is an overly cautious approach, and there remains a need to find an optimal design method for a building's foundations. Such a solution may be the piled raft foundation, which allows a reduction of the number of piles due to the integration of the raft in the bearing capacity of the foundation.

The aim of this article is to estimate the contribution of foundation elements such as the raft and the piles in the bearing capacity of a residential building located in Warsaw, where the geological conditions are characterized by organic soil layers, principally of gyttja. In the analysed case, a layer of sand extends to an approximate depth of $7 \mathrm{~m}$ below the ground level, under which is a $6 \mathrm{~m}$ thick layer of gyttja. Below this organic soil layer there is a layer of high elasticity modulus clayey sands and fine-grained sands. The foundation of the building is a $1.30 \mathrm{~m}$ thick raft at a depth of approximately $10.50 \mathrm{~m}$ below ground level, supported by a group of 95 barrettes each $80 \times 280 \mathrm{~cm}$ in section with an average axial spacing of $5.5 \mathrm{~m}$. 0.8 -meters-thick diaphragm walls enclose the underground part of the structure, and 


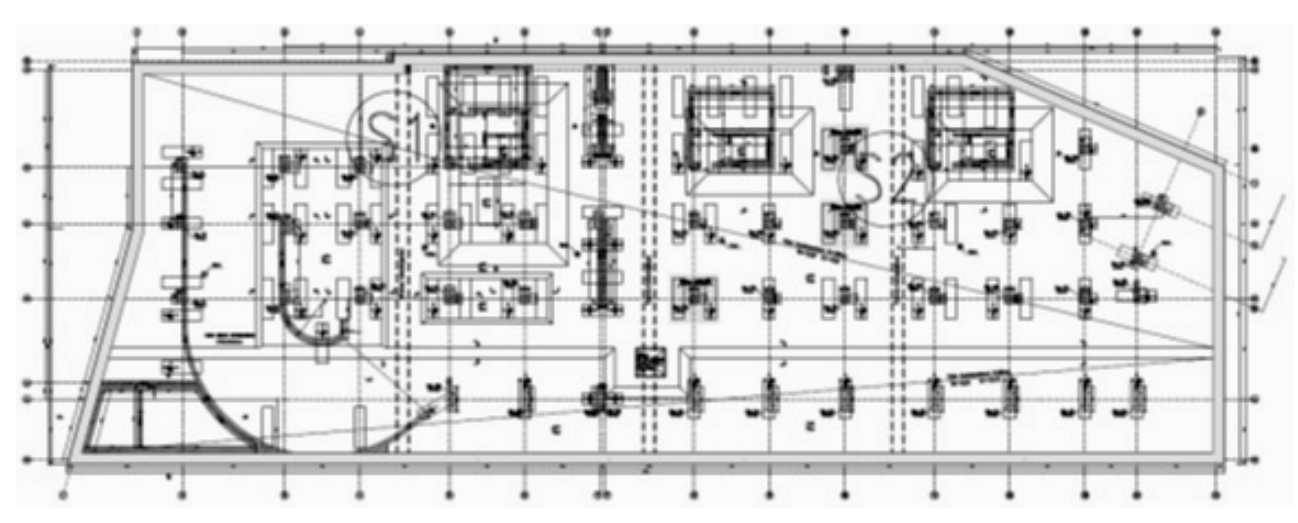

FIGURE 1. Structural scheme of foundation raft

also represent an additional peripheral support for the foundation raft. A plan of the foundation raft is shown in Figure 1.

The main feature of the piled raft foundation is the cooperation of both piles and raft with the soil underneath the foundation. These mutual interactions make it difficult to determine the bearing capacity - or rather the contribution to the total bearing capacity - of each of the constituent elements in interactions: the pile-soil, the pile-pile, the raft-soil, and the pile-raft. With a system of such complexity, the simplified assumption is widely adopted that the total load is transmitted through the piles only. This approach could be considered as close to correct (the approach is precautionary because of the absence of contact between the raft and its underlying soil) if the stiffness of each pile were determined correctly. A common mistake made by designers is to assume perfectly rigid supports in the places of piles under the raft. Such a design leads to a lack of additional pressure on the raft, which should be taken into account during element dimensioning.

In the case of a piled foundation, the main concern is the bearing capacity of the group of piles, and thus the settlement of the group. It is certain that the settlement of a group of piles is greater than the settlement of a single pile under the same geological conditions. This is explained by the interactions between the piles and the penetration and overlapping of the displacement volumes around each pile. Piles in a group do not settle evenly. Vertical displacements of the inner piles differ from those of corner piles. Due to the overlapping of stress zones around the piles one can assume that the inner piles will settle more than the piles located at the edge/in the corner of the group, i.e. the stiffness of an inner pile is lower than that of an outer or corner one.

In fact, it is challenging to determine the contribution to the bearing capacity of every pile in a pile group and in a piled raft foundation. An approximate method 
may involve the estimation of the settlement of individual components, and then an attempt to define their mutual cooperation. On the basis of separately estimated settlements of the raft and of a single pile one can calculate the stiffness coefficients separately for the raft in contact with the soil which takes into account the displacements and for piles in the group.

\section{SOIL STIFFNESS}

The soil stiffness coefficient is the ratio of the load to the settlement induced by this load:

$$
k_{z}=\frac{q}{s}
$$

where:

$k_{z}$-stiffness coefficient of the soil below the foundation raft;

$q$ - the load applied on the raft which is uniformly distributed on the soil underneath; $s$ - settlement of the raft under the applied load.

Settlements are part of the serviceability limit state, which is verified for characteristic load: therefore for the calculations of both the soil's and the pile stiffness coefficients one should use the characteristic loads. The calculation of the soil stiffness coefficient is reduced to the calculation of the settlement of the raft under a certain load. There are different ways of determining the raft's settlements. The following are the description of three methods, which were used in the analysis of the foundations of the building in Warsaw.

\section{The stiffness of the layered soil according to Meyer (2012)}

The author in his work gives the following way to calculate the stiffness of the layered soil (Fig. 2).

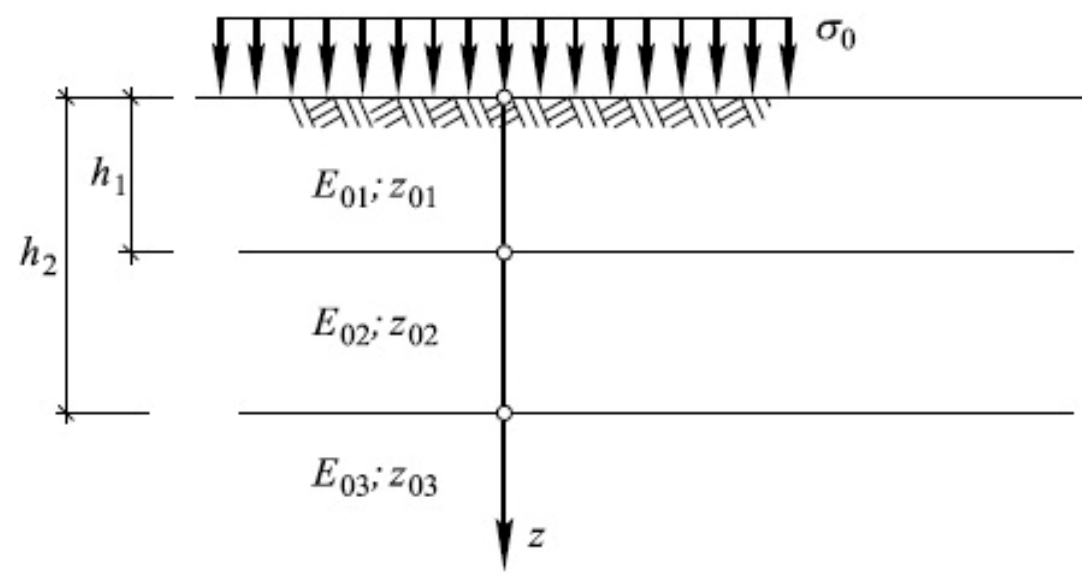

FIGURE 2. A scheme of the raft's settlement on layered substrate (Meyer 2012) 
The author gives the following formula to determine the soil stiffness coefficient for three-layered soil
$M_{0 i}$ - oedometric modulus of primary compression determined for the soil layer $i$;

$$
k=\frac{1}{\frac{z_{01}}{E_{01}} \cdot \frac{h_{1}}{z_{01}+h_{1}}+\frac{z_{02}}{E_{02}} \cdot \frac{z_{02} \cdot\left(h_{2}-h_{1}\right)}{\left(z_{02}+h_{2}\right)\left(z_{02}+h_{1}\right)}+\frac{z_{03}}{E_{03}} \cdot \frac{z_{03}}{z_{03}+h_{1}+h_{2}}}\left[\frac{\mathrm{kN}}{\mathrm{m}^{3}}\right]
$$

where:

$E_{0 i}$ - oedometric modulus of the $i$-soil layer $[\mathrm{kPa}]$,

$h_{i}-$ depth of the soil layer [m],

$z_{0}$ - the boundary of the active zone [-].

\section{One-dimensional deformation method}

Settlements can be calculated according to the method of one-dimensional deformations given in PN-81/B-03020 and ITB instruction (Geotechnika 2000) as an amendment to Polish standard. According to the instruction the settlement of the $i$-layer $s_{i}$ depends on the stress relation from the building's load $\sigma_{z q}$ and unloading resulting from the excavation $\sigma_{z s}$ if $\sigma_{z q}>\sigma_{z s}$ (in the case of shallow depths)

$$
s_{i}=s_{i}^{\prime \prime}+s_{i}^{\prime}=\lambda_{i} \cdot \frac{\sigma_{z s i} \cdot h_{i}}{M_{i}}+\frac{\sigma_{z d i} \cdot h_{i}}{M_{0 i}}
$$

if $\sigma_{z q} \leq \sigma_{z s}$ (in the case of deep depths)

$s_{i}=s_{i}{ }_{i}+s_{i}^{\prime}=\lambda_{i} \cdot \frac{\sigma_{z s i} \cdot h_{i}}{M_{i}}+\frac{\left(\sigma_{z q i}-\sigma_{z s i}\right) \cdot h_{i}}{M_{i}}$

where:

$M_{i}$ - oedometric modulus of the $i$-soil layer determined in unloading; $\lambda$ - coefficient that takes into account the degree of unloading of the soil at the time of execution of the foundation: $\lambda=0.7$ - for non-cohesive soils; $\lambda=0.5-$ for cohesive soils.

\section{Three-dimensional deformation method}

Another method to calculate the settlement of the foundation can be the three-dimensional deformation method (Wiłun 2010):

$s_{i}=\left(\frac{\sigma_{z s D}}{\delta \cdot M_{i}}+\frac{\sigma_{z d D}}{\delta \cdot M_{0 i}}\right) \cdot B \cdot \Delta \omega_{i} \cdot\left(1-v_{i 0}^{2}\right)$

where:

$\sigma_{z s D}-$ secondary stress at foundation level;

$\sigma_{z d D}-$ additional stress at foundation level;

$M_{i}$ - secondary oedometric modulus determined for the soil layer $i$;

$M_{0 i}$ - primary oedometric modulus determined for the soil layer $i$;

$B$ - width of the foundation;

$v_{0}$ - lateral expansion coefficient;

$\delta-$ coefficient depending on the soil's expansion coefficient; 


$$
\delta=\frac{\left(1+v_{0}\right)\left(1-2 v_{0}\right)}{1-v_{0}}
$$

$\omega$ - influence coefficient, depending on the shape of the load area (foundation) and the stiffness and the location of the point relative to the loaded area

$$
\Delta \omega=\omega_{i+1}-\omega_{i}
$$

\section{Active settlement zone}

When one is calculating large raft foundations, determining the depth of the active zone of settlement becomes problematic (Wiłun 2010). The depth of active zone for settlement calculated for large foundation element as a raft becomes very large (unrealistically large and consequently, one obtains excessive settlements), even when the calculations are based on the more optimistic standard PN-B-03020:1981. Very difficult and laborious calculations ensue. The solution to this problem could be a separation of the foundation into smaller parts and to consider their separate settlements. However, in this case, the designer has to be aware of the influence of the neighbouring foundations on every separate part. Meyer (2012) answered the question whether there is a size limit beyond which the settlements no longer increase. According to Meyer (2012), the equation to calculate the settlement of a foundation is a function of an independent variable $\frac{\gamma \cdot B}{\sigma_{0}}$, which reaches a maximum at the $\frac{\gamma \cdot B_{\max }}{\sigma_{0}}$ point. This indicates that to calculate raft settlement it is sufficient to determine the vertical displacements of a square raft of side length $\frac{\sigma_{0}}{\gamma}$, where are $\sigma_{0}$ the stresses at the raft-soil contact zone, and $\gamma$ is the bulk unit weight of the soil beneath the raft.

\section{THE STIFFNESS OF A SINGLE PILE}

The calculation of the (axial) stiffness coefficient of the piles is reduced to the calculation of the settlement of a single pile with a certain load applied, and then to the calculation of settlement of the pile group using appropriate coefficients. One way to determine the value of the settlement of a single pile is described in the PN-83/B-02482. However, it should be noted that the load-settlement relationship and thus the stiffness coefficient of the piles vary linearly. This is contrary to the primary assumption, which assumes that the settlement curves converge asymptotically to the limit bearing capacity of the pile (non-linear relationship). Therefore it gives us a very safe estimation of the pile load-settlement curve. As engineering practice shows, the values of settlements of individual piles based on the formula given in the Polish standard are overestimated. Therefore one should define the stiffness of piles based on load test results, or when there are no such results, on the basis of databases obtained from tests performed under comparable ground conditions. 


\section{The use of CPT results}

According to PN-EN 1997-1:2008, piles can be designed based on empirical or analytical calculation methods of which the reliability has been demonstrated by static load tests in similar ground conditions. The static CPT method is one such method. This method has been thoroughly described in Gwizdała (2009). It shows how to determine the $q_{b u}$ and $q_{\text {su }}$ values that are used to determine the settlement curve (the load-settlement dependence). For this purpose, curvilinear transformation functions are used describing the relationship between the friction resistance on the pile shaft and its displacement ( $\mathrm{t}-\mathrm{z}$ curve), and the relationship between the bearing resistance of the pile base and its displacement (q-z curve). The authors propose to approximate these curves with the following power function for the pile base and the pile shaft resistance.

For the pile base resistance equation takes a form

$$
\begin{aligned}
& q=q_{b u} \cdot\left(\frac{z}{z_{f}}\right)^{\beta} \text { for } z \leq z_{f} \\
& q=q_{b u} \text { for } z>z_{f}
\end{aligned}
$$

where:

$q$ - pile base resistance [kPa];

$q_{b u}$ - bearing capacity of the soil beneath pile base [kPa];

$z$ - pile head displacement [-];

$z_{f}$ - the displacement of the pile head, at which the soil bearing capacity under the pile base is mobilized [-].
For the pile shaft resistance equation takes a form

$$
\begin{aligned}
& t=t_{s u} \cdot\left(\frac{z}{z_{f}}\right)^{\alpha} \text { for } z \leq z_{v} \\
& t=t_{s u} \text { for } z>z_{v}
\end{aligned}
$$

where:

$t$ - pile shaft resistance [kPa];

$t_{s u}$ - shaft capacity $[\mathrm{kPa}]$;

$z$ - pile head displacement [-];

$z_{v}$-displacement of the pile head at which shaft capacity is mobilized [-].

According to Gwizdała [2011], values of the $z_{f} z_{v}, \alpha$ and $\beta$ coefficients depend on the type and technology of piles (boring, driving, etc.) and on the soil type.

\section{Use of the pile-load test results}

A way to calculate the settlement of a pile is to use the results of a load test carried out under corresponding loads and geological conditions. Most often, the test piles are loaded only to the designed value which corresponds only to the initial part of the settlement curve. On the basis of these results, according to $\mathrm{PN}-83 / \mathrm{B}-02482$, one can determine the maximum load that can the pile can bear and the corresponding maximum settlement. When analysing the foundation of our building we used one load test result that was carried out for a barrette of the neighbouring building. In that study, one determined the settlements for the load range between 0 to $6000 \mathrm{kN}$. Based on these results, the estimated ultimate bearing capac- 
ity load is equal to $15,111 \mathrm{kN}$, which corresponds to a settlement of $34.4 \mathrm{~mm}$. The next step is to determine the (axial) stiffness coefficient of piles based on the load test and on the end point coordinates (ultimate force $1511 \mathrm{kN}$ and corresponding settlement $34.4 \mathrm{~mm}$ ).

One of the methods for the settlement curve approximation is determined by Gwizdała (2013) and it is the modified hyperbolic dependence. The results of measurement are approximated with the linear function as follows

$$
\frac{s}{Q}=a_{l}+b_{l} \cdot s\left[\frac{\mathrm{mm}}{\mathrm{kN}}\right]
$$

The obtained parameters $a_{l}$ and $b_{l}$ allow the determination of the asymptote $b_{f}=\frac{1}{b_{1}}$, which is used to describe the settlement curve

$$
Q(\mathrm{~s})=\frac{s}{a_{l}+\frac{s}{R_{f} \cdot Q_{f}}}[\mathrm{kN}]
$$

where:

$Q(\mathrm{~s})$ - hyperbolic settlement curve [-];

$b_{f} \quad$ - asymptote of the hyperbola [-];

$Q_{f} \quad$ - ultimate load [kN];

$R_{f}$ - factor that takes into account the ultimate load and the asymptote [-].

According to Poulos (Hemsley 2000), the curve describing the variation of the (axial) pile stiffness in function of the load can be described by the following hyperbolic equation

$$
K_{z}(Q)=K_{p o c z} \cdot\left(1-R_{f} \cdot \frac{Q}{Q_{\max }}\right)
$$

where:

$K_{\text {pocz }}-$ initial axial stiffness coefficient (for small forces);

$R_{f} \quad$ - hyperbolic curve constant (recommended 0.5 for the shaft and 0.9 for the base of the pile);

$Q_{\max }$ - ultimate limit bearing capacity of the pile.

The interpretation of pile load test results are described by Meyer (2012). The obtained load test results can be approximated with a curve described by the following formula

$$
s=-C \cdot Q_{\max } \cdot \ln \left(1+\frac{Q}{Q_{\max }}\right)
$$

where:

C - initial stiffness coefficient (for small forces) [-];

$Q_{\max }$ - base capacity [kN].

The interpretation of the load test results for the barrette using the above methods is shown on Figure 3.

In addition, the load test results were used to verify the accuracy of the approximation of the settlement curve defined by the transformational function presented in Gwizdała (2011) used to calculate the load-bearing capacity and settlement of piles based on CPT results Gwizdała et al. (2009). Even though the tested barrette was placed in cohesive soils (gyttjas, clay) and calculations were done with transformation functions corresponding to large diameter piles in non-cohesive soils, the convergence of the results turned out to be significant. 


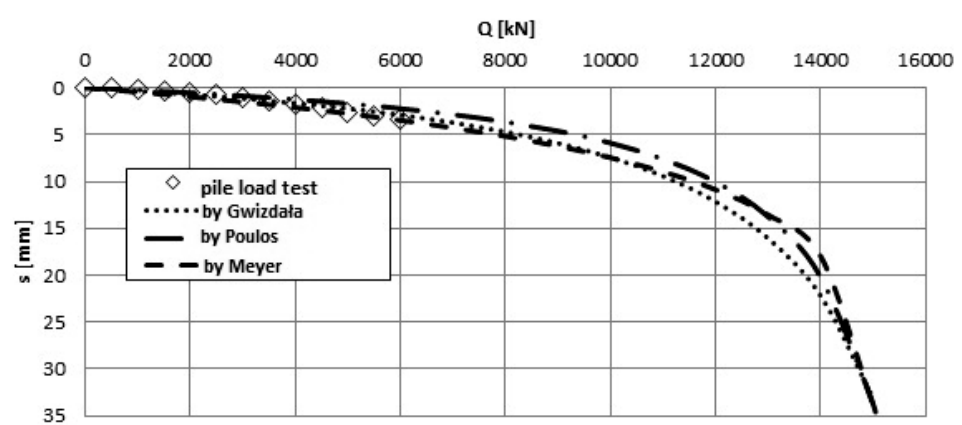

FIGURE 3. Interpretation of the pile load test with use of different methods of approximation

For further analysis, the piles coefficients adopted depend on the location of the CPTs (CPT1-CPT5) - Table 1 . Because the pile stiffness coefficient depends on the load value, the calculations of the model were carried out by iteration procedure. The algorithm in the ABC software (Pro-Soft CD) consists of an initial assumption of nodal supports with the pile stiffness coefficients, and verifies whether the response of the supports does not exceed the maximum value for which this factor was adopted. Once the conditions are satisfied, the supports are replaced by a Winkler soil model with the given barrette sectional area.
TABLE 1. Average pile stiffness

\begin{tabular}{|l|c|c|}
\hline \multirow{2}{*}{ CPT } & \multicolumn{2}{|c|}{$\begin{array}{c}\text { The stiffness of an individual pile } \\
\text { (barrette) }\end{array}$} \\
\cline { 2 - 3 } & $\mathrm{kN} / \mathrm{mm}$ & $\mathrm{MPa} / \mathrm{m}$ \\
\hline CPT1 & 5000 & 2232 \\
\hline CPT2 & 3333 & 1488 \\
\hline CPT3 & 1656 & 739 \\
\hline CPT4 & 1250 & 558 \\
\hline CPT5 & 1000 & 446 \\
\hline
\end{tabular}

Significant deviations from the piles' stiffness given in Table 1 are due not only to differences in geotechnical parameters, but mainly to varying values of loads per pile (different stiffness at point A and point B as shown in Figure 4). This is due to the non-linear nature of the piles' stiffness.

FIGURE 4. Interpretation of the pile load test with use of power function approximation

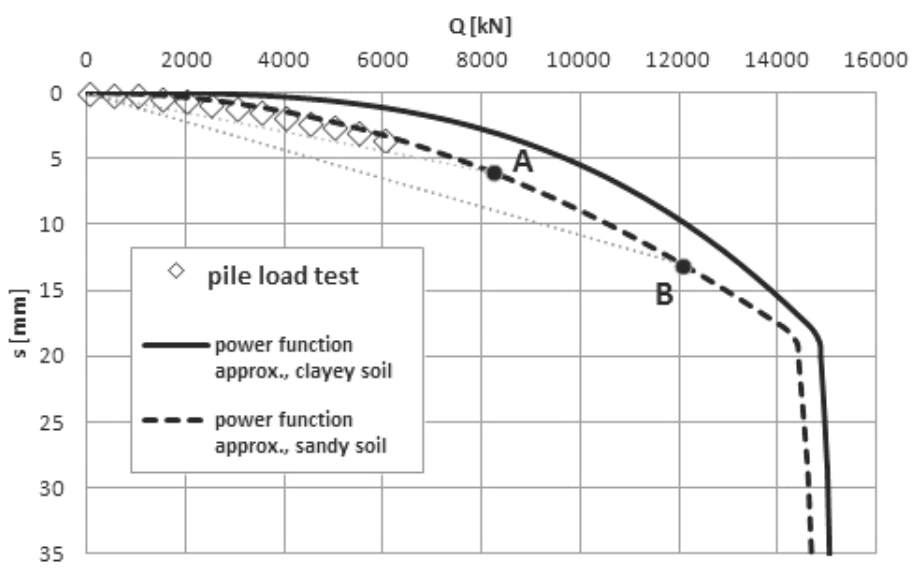




\section{PILE STIFFNESS IN A PILE GROUP}

Once we know the (axial) stiffness coefficient for a single pile, we can determine the settlement coefficient of a single pile in the group. To determine it, one can use different design approaches:

1) consider the stiffness of the raft and of separate pile groups;

2) consider the stiffness of the raft and of individual piles on the basis of the load-settlement curve of a single pile in a pile group, taking into account its location.

In the first case, the determination of the stiffness of the pile group is, in most cases, based on the values of settlements considered for individual piles. Empirical methods for calculating the settlement of a pile group give the following dependence between the settlements of a pile group and an individual pile

$$
s_{G}=s_{p} \cdot R
$$

where:

$s_{G}-$ settlement of a pile group;

$s_{p}$ - settlement of an individual pile, for the same load and ground conditions,

$R$ - coefficient taking into account the increase of the pile group settlement in relation to the settlement of an individual pile.

The work of Gwizdała et al. (2009) presents formulas for calculating the $\mathrm{R}$ coefficient (Table 2).
Knowing the $\mathrm{R}$ coefficient one can determine the value of the settlement of a pile group and therefore, the stiffness coefficients of the pile group

$$
K_{z, G}=\frac{Q}{S_{G}}=\frac{Q}{S_{p} \cdot R}=\frac{1}{R} \cdot \frac{Q}{S_{P}}=\zeta \cdot K_{z}
$$

where:

$\zeta$ - settlement ratio describing the dependence between the (axial) stiffness of piles in a group and an individual pile [-].

Another approach, for the foundation calculation, is the use of the stiffness of separate piles based on the load-settlement dependence of a single pile in the pile group, taking into account its location. The authors of the German handbook Kombinierte Pfahl-Plattengründungen (1977) showed in their work the different values of the stiffness coefficients of piles in the pile group, in dependence on their location. The settlement coefficients for piles in a group were estimated for the Frankfurt clays. When comparing the geotechnical parameters of soils in Frankfurt and the ones present in the analysed area, the settlements coefficients of a pile group have to be adjusted accordingly to the elasticity modulus. The adjusted coefficients for piles in pile groups $\left(\zeta_{\mathrm{j}}\right)$ that have been adopted in the calculations are shown in Table 3. 
TABLE 2. Overview of the empirical formulas for the R coefficient (Dyka and Gwizdała 1998)

\begin{tabular}{|c|c|c|c|}
\hline Author & Formula & Explanations & $\begin{array}{l}\text { Comments and range } \\
\text { of applicability }\end{array}$ \\
\hline $\begin{array}{l}\text { Skempton, } \\
\text { Yassin, } \\
\text { Gibson }\end{array}$ & $R=\frac{(4 B+3)^{2}}{(B+4)^{2}}$ & $\begin{array}{l}B \text { - width of the pile } \\
\text { group }\end{array}$ & $\begin{array}{l}\text { Based on field obser- } \\
\text { vations; driven piles in } \\
\text { non-cohesive soils }\end{array}$ \\
\hline Meyerhof & $R=\frac{\frac{r}{D}\left(5-\frac{r}{3 D}\right)}{\left(1+\frac{1}{n}\right)^{2}}$ & $\begin{array}{l}r \text { - piles' axial spacing } \\
D \text { - piles' diameter } \\
n-\text { the number of rows } \\
\text { of piles of equivalent } \\
\text { square }\end{array}$ & $\begin{array}{l}\text { On the basis of small- } \\
\text {-scale models; } \\
\text { Square driven pile } \\
\text { groups in non-cohe- } \\
\text { sive soils }\end{array}$ \\
\hline Vesic & $R=\sqrt{\frac{B}{D}}$ & $\begin{array}{l}B \text { - width of a pile group } \\
D \text { - piles' diameter }\end{array}$ & $\begin{array}{l}\text { On the basis of real } \\
\text { scale measurements }\end{array}$ \\
\hline Berezancew & $R=\frac{\sqrt{A_{2}}}{\sqrt{A_{1}}}$ & $\begin{array}{l}A_{1}, A_{2}-\text { surface areas of } \\
\text { the base of the equivalent } \\
\text { raft foundations }\end{array}$ & \\
\hline Poulos & $R_{n}=\left(R_{25}-R_{16}\right)(\sqrt{n}-5)+R_{25}$ & $\begin{array}{l}n-\text { number of piles in } \\
\text { a group } \\
R_{25}-\text { coefficient for } \\
\text { a pile group consisting } \\
\text { of } 25 \text { piles } \\
R_{16}-\text { coefficient for } \\
\text { a pile group consisting } \\
\text { of } 16 \text { piles }\end{array}$ & $\begin{array}{l}\text { Values of the coef- } \\
\text { ficients based on } \\
\text { theoretical analysis } \\
\text { in a tabulated form } \\
\text { (Mindlin solution); } \\
\text { square pile group with } \\
\text { a rigid raft }\end{array}$ \\
\hline $\begin{array}{l}\text { Italian } \\
\text { guidelines } \\
\text { AGI-1984 }\end{array}$ & $\begin{array}{l}R=\left(\frac{1.2 B+2.7}{0.3 B+4}\right)^{2}-\text { driven piles } \\
R=\left(\frac{0.6 B}{0.3 B+0.3}\right)^{2}-\text { bored piles }\end{array}$ & $B$ - width of the pile group & \\
\hline Fleming & $R=n^{w}$ & $\begin{array}{l}n-\text { number of piles in } \\
\text { a group } \\
w-\text { power series exponent } \\
(w=0.4-0.6)\end{array}$ & $\begin{array}{l}\text { On the basis of calcu- } \\
\text { lations: } \\
\text { L / D }>25\end{array}$ \\
\hline Van Impe & $R=\left(C_{1}+C_{2} \frac{r}{D}\right) \frac{3 B^{2}-r^{2}-2 B r}{B r}$ & $\begin{array}{l}C_{1}=2.266 \\
C_{2}=-0.427 \\
r-\text { piles' axial spacing } \\
B-\text { width of the pile group } \\
D-\text { piles' diameter at base }\end{array}$ & $\begin{array}{l}\text { If the ratio of the sum } \\
\text { of the cross-sections } \\
\text { of all the piles to the } \\
\text { cross-section of the } \\
\text { entire group satisfies } \\
\text { the condition: } \\
\omega=\frac{\sum A_{p}}{B L} \geq 10 \%\end{array}$ \\
\hline Mandolini & $R=0.34 \sqrt{\frac{n L}{r}}$ & $\begin{array}{l}L-\text { piles' length } \\
n-\text { number of piles in } \\
\text { a group } \\
r \text { - piles' axial spacing }\end{array}$ & $\begin{array}{l}\text { On the basis of } 104 \\
\text { model tests and field } \\
\text { measurements }\end{array}$ \\
\hline
\end{tabular}


TABLE 3. Assumed settlement coefficients for pile in a pile group $\left(\zeta_{j}\right)$

\begin{tabular}{|c|c|c|c|c|}
\hline \multicolumn{2}{|c|}{ Foundation type } & \multicolumn{3}{|c|}{$\begin{array}{l}\text { The settlement coefficient for a pile in a pile group depending on } \\
\text { the pile location }\end{array}$} \\
\hline $\begin{array}{l}\text { normalized axial } \\
\text { distance between } \\
\text { piles }\end{array}$ & $\begin{array}{l}\text { normalized } \\
\text { pile length }\end{array}$ & $\begin{array}{c}\text { inner pile } \\
\left(\zeta_{Z}\right)\end{array}$ & $\begin{array}{l}\text { edge pile } \\
\left(\zeta_{R}\right)\end{array}$ & $\begin{array}{c}\text { corner pile } \\
\qquad\left(\zeta_{E}\right)\end{array}$ \\
\hline \multicolumn{5}{|c|}{ CPRF (combined piled raft foundations) } \\
\hline $\mathrm{e} / D=3.0$ & $1 / D=10$ & 0.11 & 0.17 & 0.26 \\
\hline \multicolumn{2}{|c|}{$\begin{array}{l}\text { Adjusted coefficients of soils for } \\
\text { the building in Warsaw }\end{array}$} & 0.14 & 0.22 & 0.34 \\
\hline
\end{tabular}

$e$-pile axial spacing in a group; $D$ - pile diameter; $l$ - pile length.

$$
\zeta_{j}=\frac{c_{P f, j}}{c_{P f, P}}
$$

where:

$\zeta_{j}-$ pile settlement coefficient in the pile group;

$c_{P f, j}-$ pile stiffness coefficient in the pile group;

$c_{P f, P}-$ stiffness coefficient of an individual pile.

The second approach showing the effect of the location of the pile in the group on its bearing capacity is explained in another German guidebook, EA-Pfähle (2014). Depending on the location of the pile in the group, whether it is an inner pile, an edge pile or a corner pile, the contribution of the transmission of the forces is different, which can be read from the nomograms shown in Figures 5-7. They depend on the ground conditions and the values of the settlements:

In this design, pile settlement coefficients in the pile group according to (Hanisch et al. 1997) were adopted, which in comparison with the recommendation (EA-Pfähle 2014) give a lower resistance and thus lower stiffness of the pile group. This approach ensures more building security.

In addition, it is worth paying attention to the procedure of estimating the contribution of the diaphragm walls to the bearing capacity of the foundation. Although diaphragm walls play mainly the role of securing the stability of the trench, they also take part in the transmission of loads on the foundation. Their structure is composed of independent segments therefore their stiffness coefficient can be calculated likewise for piles (single barrettes). Due to the fact that the diaphragm wall is a straight line of barrette sections, the stiffness coefficients were multiplied by a value of 0.14 which corresponds to $\zeta_{j}$ of the inner pile in the combined piled raft foundation. Such an approach is supported by the fact that the barrette sections as part of the diaphragm wall are located very close to each other, resulting in overlapping of the stress and settlement zones, likewise for the inner piles. 

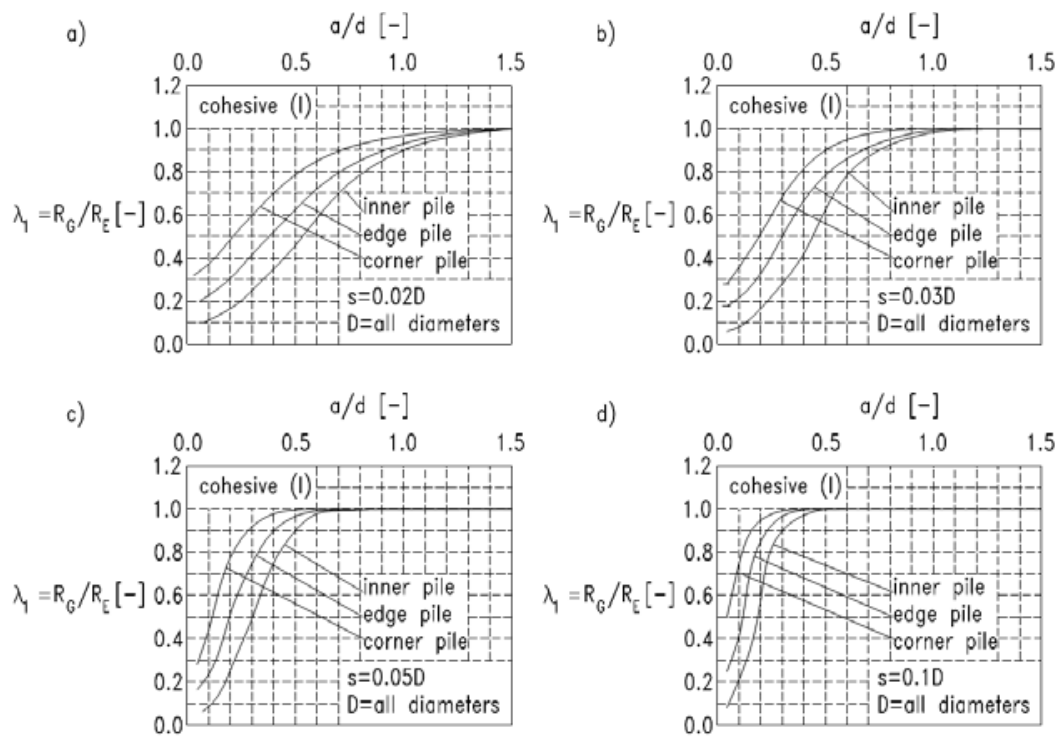

$R_{G}$ - bearing capacity of the pile in a pile group; $R_{E}$ - bearing capacity of an individual pile; $a$ - axial spacing between piles in a pile group; $d$ - length of pile immersed in the bearing layer; $D$ - pile diameter.

FIGURE 5. Nomograms showing the dependence of the bearing capacity of a pile in a pile group to a single pile, determined for cohesive soils $E=5-15 \mathrm{MPa}$, for different values of settlements: a $-s=0.02 D$, $\mathrm{b}-s=0.03 D, \mathrm{c}-s=0.05 D, \mathrm{~d}-s=0.1 D($ EA-Pfähle 2014)
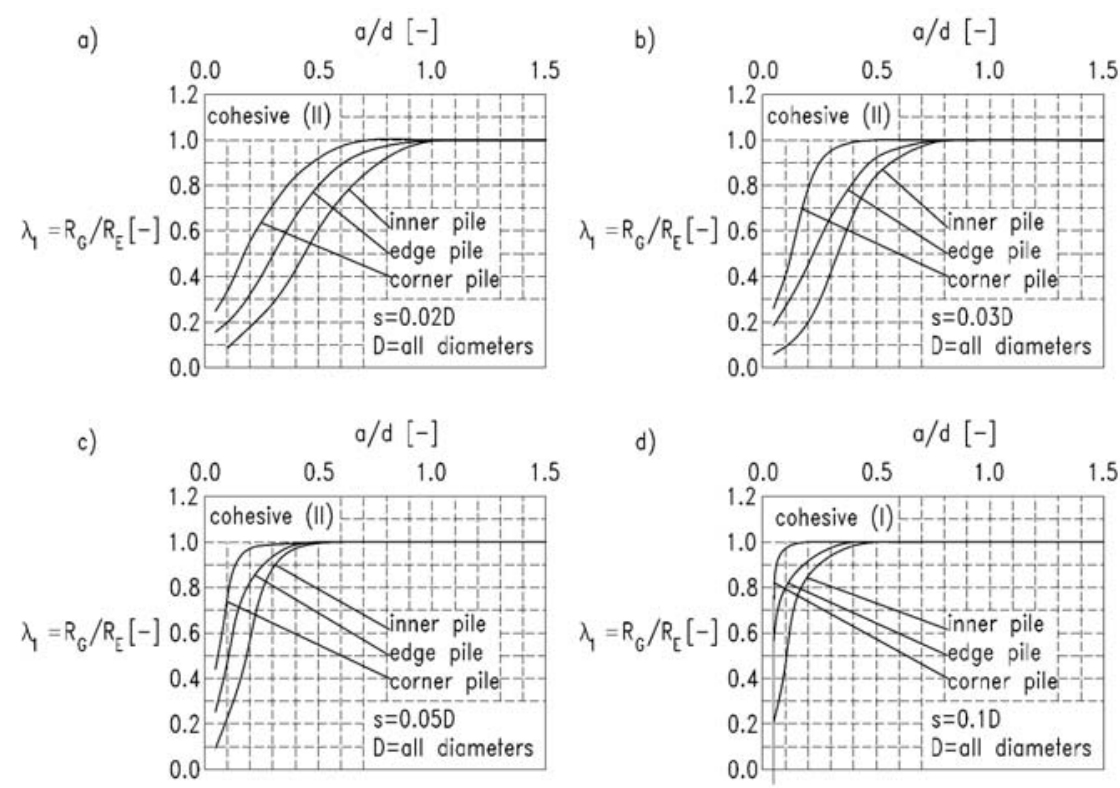

FIGURE 6. Nomograms showing the dependence of the bearing capacity of a pile in a pile group to a single pile, determined for cohesive soils $\mathrm{E}=15-30 \mathrm{MPa}$, for different values of settlements: $\mathrm{a}-s=0.02 D$, $\mathrm{b}-s=0.03 D, \mathrm{c}-s=0.05 D, \mathrm{~d}-s=0.1 D$ (EA-Pfähle 2014) 

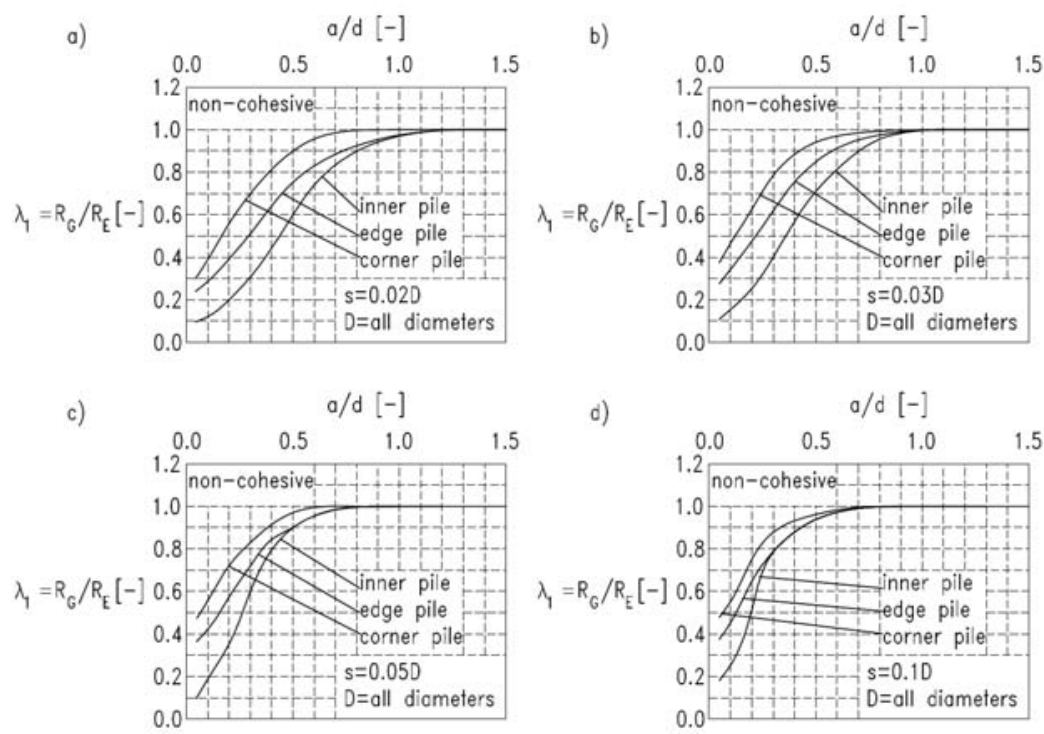

FIGURE 7. Nomograms showing the dependence of the bearing capacity of a pile in a pile group to a single pile, determined for non-cohesive soils $E \geq 25 \mathrm{MPa}$, for different values of settlements: a $-s=0.02 \mathrm{D}$, $\mathrm{b}-s=0.03 D, \mathrm{c}-s=0.05 D, \mathrm{~d}-s=0.1 D$ (EA-Pfähle 2014)

\section{THE CONCLUSIONS AND RESULTS OF THE ANALYSIS}

The presented methods of stiffness coefficient calculations for both soil and piles, taking into account the interaction of a group of piles, allow the creation of a finite element model in ABC Płyta. The adopted model of the foundation on a piled raft system shows that the maximum calculated settlement does not exceed $23 \mathrm{~mm}(22.31 \mathrm{~mm})$. For the dimensioning of the reinforcement of the raft, due to bending, the analysis should be performed by taking into account upper and lower stiffness estimates.

This issue is very complex and it is very challenging to prove the correctness of predictions, even with complex FEM analysis that is not more reliable.
In such designs it is recommended to measure displacements of the structure by surveying methods. A properly designed monitoring system and measurements of settlements will allow to gain valuable experience.

\section{REFERENCES}

DYKAI., GWIZDAŁAK. 1998: Metody obliczeń osiadania dużych grup palowych. Inżynieria Morska i Geotechnika (5), 248-255.

EA-Pfähle. Recommendations on piling 2014. DGGT/Ernst \& Sohn.

Geotechnika. Projektowanie posadowień bezpośrednich. Zmiana PN-81/B-03020. Konferencja Naukowo-Techniczna "Harmonizacja polskich norm geotechnicznych z systemem norm europejskich", Vol. 1. Mragowo, listopad 2000.

GWIZDAŁA K. 2011: Fundamenty palowe. Technologie i obliczenia Wydawnictwo Naukowe PWN, Warszawa. 
GWIZDAŁA K. 2013: Fundamenty palowe. Badania i zastosowania. Vol. 2. Wydawnictwo Naukowe PWN, Warszawa.

GWIZDAŁA K., STĘCZNIEWSKI M., DYKA I. 2009: Wykorzystanie sondowań statycznych do obliczania nośności i osiadań pali. Nowoczesne Budownictwo Inżynieryjne 4 (25), 62-69.

HANISCH J., KATZENBACH R., KÖNIG G. 1977: Kombinierte Pfahl-Plattengründungen. Warszawa.

HEMSLEY J. 2000: Design applications of raft foundation. Thomas Telford, London.

MEYER Z. 2012: Obliczenia inżynierskie osiadania fundamentów. ZAPOL, Szczecin.

PN-81/B-03020. Grunty budowlane. Posadowienie bezpośrednie budowli. Obliczenia statyczne i projektowanie. PKN, Warszawa.

PN-83/B-02482. Fundamenty palowe. PKN, Warszawa.

PN-EN 1997-1:2008. Eurokod 7 - Projektowanie geotechniczne. Część 1: Zasady ogólne. PKN, Warszawa.

Pro-Soft, Krzysztof Grajek, ABC - Płyta. Wersja 6.2: Opis programu, Gliwice, 2004.

WIŁUN Z. 2010: Zarys geotechniki. Wydawnictwo Komunikacji i Łączności, Warszawa.

Streszczenie: Uproszczony algorytm do projektowania fundamentów plytowo-palowych na przykładzie budynku posadowionego w obrębie rynny żoliborskiej. Powszechną praktyką inżynierską w przypadku zbyt dużych osiadań dla tradycyjnych posadowień bezpośrednich jest stosowanie pali w celu ograniczenia nadmiernych przemieszczeń opartej na nich konstrukcji. W takiej metodzie najczęściej całkowite obciążenie przekazywane jest na pale. Jest to podejście nadmiernie ostrożne, stąd potrzeba znalezienia optymalnego podejścia projektowego dla posadowień budowli. Takim rozwiązaniem mogą być fundamenty płytowo-palowe, które pozwalają ograniczyć liczbę pali ze względu na włączenie do współpracy elementu posadowienia bezpośredniego, którym jest płyta fundamentowa. Niniejszy artykuł ma na celu przedstawienie próby oszacowania udziału takich elementów jak płyta i pale w przenoszeniu obciążeń na przykładzie budynku mieszkalnego zlokalizowanego w Warszawie w obszarze rynny żoliborskiej, w obrębie której warunki gruntowe charakteryzują się występowaniem gruntów organicznych, tzw. gytii.

Stowa kluczowe: fundament płytowo-palowy, rynna żoliborska

MS. received May 2015

\section{Authors' address:}

Grzegorz Kacprzak

Wydział Inżynierii Lądowej PW

Instytut Dróg i Mostów

al. Armii Ludowej 16, 00-637 Warszawa,

Poland

e-mail: g.kacprzak@il.pw.edu.pl 